\title{
Chinese engineers and information technology in Japan
}

On-line work and the rise of virtual migration

Wang Jin

\section{(2) OpenEdition}

\section{Journals}

Édition électronique

URL : http://journals.openedition.org/chinaperspectives/524

DOI : $10.4000 /$ chinaperspectives.524

ISSN : 1996-4617

Éditeur

Centre d'étude français sur la Chine contemporaine

Édition imprimée

Date de publication : 1 octobre 2005

ISSN : 2070-3449

\section{Référence électronique}

Wang Jin, « Chinese engineers and information technology in Japan », China Perspectives [En ligne],

61 | september-october 2005, mis en ligne le 01 octobre 2008, consulté le 28 octobre 2019. URL

http://journals.openedition.org/chinaperspectives/524 ; DOI : 10.4000/chinaperspectives.524

Ce document a été généré automatiquement le 28 octobre 2019

(c) All rights reserved 


\section{Chinese engineers and information technology in Japan}

On-line work and the rise of virtual migration

Wang Jin

1 Over the last twenty years, the information technology (IT) sector has undergone rapid changes. This is not just a matter of technical advances but of an expansion of transnational capitalism and the growing power of the multinationals. At the same time, migration patterns have also undergone considerable transformations. This article takes the example of Chinese information technologists living in Japan to highlight one aspect of this current change in migration. Since IT covers such a wide range of activities, my analysis focuses on software production, leaving aside activities concerned with hardware.

India is way ahead of China in terms of the number of IT technicians working abroad, but the proportion of Chinese in this sector is steadily expanding. Moreover, unlike the Indians, the Chinese workers are not concentrated in the United States. They are to be found throughout the developed world. Through what channels do these cutting-edge technicians make their overseas connections, gaining a reputation as winners in the new wave of migrants? What is their life-style? How are the mechanisms established which make their mobile professional life possible?

3 In order to answer these questions, while also highlighting the similarities and differences between the Chinese in Japan and the Indians in the United States, I propose to analyse and contextualise a certain number of sources, including articles from Zhongwen daobao ${ }^{1}$, which is a representative Chinese language publication in Japan, and data provided by the Japanese immigration bureau.

Chinese IT workers in Japan are becoming an identifiable social group

On July 1st 2003, the Japanese Ministry of Economy, Trade and Industry published its annual White Paper on Foreign Trade. This document stated that "allowing entry to scientifically qualified foreign workers is the basis for maintaining high standards". This was the first time that an argument for bringing in highly qualified foreign workers had been put forward in a government white paper. The section dealing with 
this issue outlined the policies adopted by other advanced countries (the United States, Britain, Germany, and France) for bringing in foreign workers, especially those in IT. In other words, the Ministry was clearly giving priority to welcoming IT workers.

5 The rapid growth of the IT and communications industries in the 1990s saw fierce competition between the United States and the other advanced countries, aimed at recruiting the most highly qualified IT workers. For this, they adopted various strategies, and very soon Japan also joined the fray. A good example was the trip to India by Mori, the Japanese prime minister at the time. This visit gave a boost to the "Project for Promoting Indo-Japanese Co-operation in Information Technology", and marked a high point in economic relations between the two countries. Shortly after this visit, the finance ministries of the ASEAN+3 countries adopted an "Initiative to Normalise IT Standards in the Asian Region", which had been proposed by Hirauma when he was the Japanese minister for Finance and Industry. Following this meeting, these countries worked together to set up common standards for recognising IT qualifications. This arrangement currently includes eight countries (see Table 1). As a result, the Japanese immigration bureau relaxed its rules, particularly for Indian IT workers, and immigration procedures quickly became simpler.

1. Countries Participating in the Arrangement for Reciprocal Recognition of IT qualifications with Japan

\begin{tabular}{|c|c|}
\hline & Number of people \\
\hline 1950 & 40,481 \\
\hline 1960 & 45,535 \\
\hline 1970 & 51,481 \\
\hline 1980 & 52,896 \\
\hline 1985 & 74,924 \\
\hline 1990 & 150,339 \\
\hline 1995 & 222,991 \\
\hline 2000 & 335,575 \\
\hline 2001 & 381,225 \\
\hline 2002 & 424,282 \\
\hline 2003 & 462,396 \\
\hline
\end{tabular}

In addition to the Japanese government, leading economic bodies, such as Keidanren, the Japanese employers' association, and the Japanese Chamber of Commerce and Industry, have openly come out in favour of opening up to qualified foreign workers, particularly in information technology.

7 As IT has undergone spectacular development in recent years, the jobs gap between supply and demand has widened in favour of further immigration. Faced with a shortage of qualified personnel, an increasing number of Japanese firms have come to rely on foreigners. In 2001, NEC took on 40 foreign IT workers, while IBM-Japan 
employs 20 Chinese engineers and intends to continue its policy of recruiting foreign workers. Likewise, Toshiba, Hitachi and Sony have all set up long term programmes to take on foreign IT workers. In the Kayabashu region, where 380 IT firms are concentrated, it is common to come across Chinese IT workers.

The 1990 law on immigration changed the conditions for granting entry work permits (see Table 2). However, there is no visa specifically allowing entry to foreign hi-tech specialists, as has been the case in the United States since Congress voted for the H1-B visa in 1991. Although Japan is at least ten years behind the United States in information technology, it seems that when it came to revising its immigration laws, the country saw no particular need to propose this type of visa. According to Table 2, before the law was revised, visas likely to affect engineers were those covering "technological co-operation" and "current employees". After the revision, it would appear that the key visas were aimed at "engineers" and "reassignments for company development". Given that the only available statistical data on this issue are from the immigration bureau of the Department of Justice, tables 3 and 4 are based on such data to provide at least some insight into the growing number of Chinese engineers in Japan.

\section{Residential Status Before and After the Cahnge in the Law on Immigration in 1990}

\begin{tabular}{|c|c|c|c|c|c|c|c|}
\hline & $\begin{array}{l}\text { Total } \\
\text { popolatiol }\end{array}$ & Mtaineus & \multirow{2}{*}{$\frac{\text { Koreasn }}{625,42}$} & \multicolumn{2}{|c|}{ Brazilialailifpind } & \multirow{2}{*}{$\frac{\text { That }}{33,736}$} & \multirow{2}{*}{ Anserfea: } \\
\hline & \multicolumn{2}{|c|}{$1,851,758424,28$} & & 268,332 & 169,359 & & \\
\hline Spouse and children of Japanege & 272,719 & 53,226 & 21,868 & 90,732 & 45,510 & 12,838 & 9,021 \\
\hline Students (college and graduate) & 110.415 & 73,795 & 17.011 & 378 & 598 & 1,760 & $1,26.3$ \\
\hline Students (1 anguage school) & 47,198 & 35,450 & 7.236 & 55 & 420 & 445 & 302 \\
\hline $\begin{array}{l}\text { Students able to exchange studen } \\
\text { for work visa }\end{array}$ & $t-v i s a$ & 1,933 & 581 & 6 & 26 & 42 & 33 \\
\hline Trainees & 39,067 & 26,945 & 185 & 143 & 2,329 & 1,421 & 18 \\
\hline Engineera & 20,717 & 12,433 & 2,682 & 39 & 759 & - & 644 \\
\hline Specialists in humanities, intern & ate 4oasE at & ereitaed & 3,509 & 71 & 460 & - & 6,987 \\
\hline EntertainerA & 58.359 & 2,762 & 777 & 241 & 46.547 & 216 & 374 \\
\hline Residents: & 243,451 & 35,020 & 3,091 & 139,826 & 28,246 & 2,011 & 1,583 \\
\hline Permanent residentil & 223,875 & 70,599 & 37,121 & 31,203 & 32,796 & 3,913 & 7,348 \\
\hline $\begin{array}{l}\text { People in irregular aituation, } \\
\text { eatimated January } 2004\end{array}$ & & 33,522 & 46,425 & 4,728 & 31,428 & 14,334 & $\overline{-}$ \\
\hline
\end{tabular}

The rapid growth in their number is plain for all to see. Between the statistics for 1959 on foreign entry and the bill to modify the immigration law in 1988, the number of people granted a visa for "technological co-operation" is extremely low, amounting to less than ten. Following the passage of the bill, the total number of people granted "engineer" status quickly rose above the thousand mark. In 1988, only five Chinese were included in the "technological co-operation" category; two years later, the number of visas issued to "engineers" reached 1,414 . So, in only a few years we saw a radical shift in policy. In 1992, the number of engineers was nearly five thousand, and by 1999 it stood at over ten thousand. Although the "engineer" visa covers a range of professionalisms, it certainly includes employment in the IT sector. Unfortunately there are no statistics specifically for that area of the economy. But still, in view of the 
fact that from $30 \%$ to $50 \%$ of engineers have a job with some connection to IT, the figures must represent several thousand individuals. Moreover, among the Chinese immigrants to Japan with a visa for "company reassignment" or "research", a large number also work in IT.

Chinese IT workers in Japan: a socially diverse group

In the statistical classification by the Japanese government, Chinese IT workers are subdivided into several categories, of which one is "engineers". We often think that, when compared with other Chinese residents, IT workers form a very homogeneous group. But, in reality, there is a very marked social stratification within this group, and the fate of each individual is largely decided even before their departure for Japan. So, in order to understand this internal diversity, it is useful to start by examining their different means of entry into the country.

At present, the entry of Chinese IT workers into Japan operates by means of four main channels.

The first of these is the recruitment of Chinese graduates from Japanese universities. The recruitment of foreigners who have completed their studies in Japan has increased enormously since 1992. This is probably a long-term trend. A closer look at the kind of employment taken up by these foreign graduates shows that the main profession is translator/interpreter, followed by employment in "technological development", with commerce and education in third place. As there are no data for each nationality, it is not possible to ascertain the proportion of Chinese in the different categories. But, since we know that Chinese students represent more than $50 \%$ of foreign graduates employed in Japan ${ }^{2}$, we can confidently state that they are a major part of the overall numbers in possession of an "engineer" visa.

The second channel, through direct recruitment in China by a Japanese firm, is subdivided into two possible routes. One way is through an employment agency which does not necessarily have any special IT connections but just sends all such workers on its books to Japan. Another way is through the direct recruitment of workers in China by Japanese IT firms. A number of these firms conduct recruitment campaigns by organising presentational gatherings in the best Chinese universities, or through publicity sheets folded into newspapers. By these methods they ensure the professional competence of those they recruit. This also means that the recruiting agencies have stringent demands: Chinese students must not only show outstanding technical capabilities, but must also be able to communicate in Japanese and work as part of a team. The personal account by a Mr. Zhang from Hangzhou bears this out: "As soon as I saw the advertisement for personnel in the newspaper, I went to the recruiting office in Shanghai. There was very fierce competition, and to come out top I learnt my CV by heart in Japanese. Everything went very smoothly, and I left for Japan without any problems" ${ }^{3}$.

Entry into Japan can also be achieved through so-called "company reassignment". In the IT sector, people with a "reassignment" visa carry out the same work as those with an engineer visa, but their status is very different. "Reassigned" people do not enjoy the same salary or prospects. The number entering Japan in this category was over one thousand in 1994, and has increased by about a hundred every year since then (see Table 4). Most of these people with IT qualifications appear to be Chinese. 
3. Number of Chinese Engineers in Japan before the Change in the Immigration Law

\begin{tabular}{|c|c|c|c|c|c|c|c|}
\hline & Total & Chinease & Korean & Brazllían & Pilipino & That: & American \\
\hline $\begin{array}{l}\text { Total number } \\
\text { of mixed marris }\end{array}$ & res36,039 & 11,132 & 7,563 & 560 & 7,911 & 1,507 & 1,685 \\
\hline $\begin{array}{l}\text { Japanese men/ } \\
\text { toreign wives }\end{array}$ & 27,881 & 10,242 & 5,318 & 295 & 7,794 & 1,445 & 156 \\
\hline $\begin{array}{l}\text { Japanese women/ } \\
\text { foreign husband }\end{array}$ & 8,158 & 890 & 2,235 & 265 & 117 & 62 & 1,529 \\
\hline
\end{tabular}

Unlike people on work-study programmes, the "reassigned" are not restricted to one year's residence by their visa conditions. In that respect, their position is better. However, as their designation infers, they have been reallocated to other jobs within the Japanese firm, and they are often employees of the firm's subsidiary in China. Consequently, they are subject to a certain number of constraints which are not imposed by the Japanese immigration bureau but by the Japanese company. Firstly, we are often told that their net pay is lower than that of their Japanese counterparts. Secondly, fearing that these employees may be poached by another company upon their arrival in Japan, a number of these companies make them sign a local employment contract and put down a deposit, before leaving China.

Lastly, Chinese workers may come to Japan on "work-study" programmes. There is a still-persisting idea that such working students perform the tasks shunned by Japanese, known as the $3 \mathrm{Ks}{ }^{4}$. Yet, over the last few years, as a consequence of the shortage of IT personnel, foreign student workers in that area, especially Chinese workers, have begun to arrive in Japan. At first, the recourse to such workers for "intellectual" work in jobs such as information technology, caused a good deal of astonishment. But, under the misleading label of "training and job practice", these work-study employees are set to become an increasingly valued labour force for Japanese companies.

The wages of the "reassigned" and student workers are low, but are a bit higher than their equivalent in China. Inasmuch as legal employment in Japan is no longer restricted to Japanese and Chinese in regular employment, taking a job in Japan becomes an option for those who are only planning a short stay. The very fact of having acquired work experience in Japan is an advantage, and there is a good chance that by going to Japan Chinese workers are giving themselves new opportunities. Working in Japan is therefore attractive, despite the low wages and the uncertain residential status.

18 According to current immigration laws, at the end of the work-study period the employee must leave the company, and may not have their visa changed to allow regular work. When an employer is satisfied with the work-study employee, the latter usually goes home for a time and then returns to Japan with a work visa. It seems that on average the visa change leads to a doubling of the worker's wages, so the number of IT workers on work-study programmes is certain to increase.

The Chinese IT workers in Japan do not form a single homogeneous block, and the internal stratification dividing them is decided even before they get to Japan. But this stratification is not set in stone. From the outset, there is a chance of passing from one status to another. In particular, an employee on a work-study programme, once he has reached Japan, and depending on the social capital that he has managed to accumulate, can swiftly eliminate the disadvantages related to his residential status, and move into 
an enviable position on a par with the Japanese or Chinese with regular employment in Japan.

The emergence of virtual migration

In considering the case of Chinese in Japan, it is not possible to simply apply Aneesh's ideas about on-line working and virtual migration (see insert). We have to expand his interpretation. The work that can be carried out on-line is not limited to programming, having already expanded in fact into several other areas of activity, in particular the financial and service sectors. Professional activities that can be carried out on-line include network architecture, developing and controlling automated production lines, and market analysis or analysis of fluctuations in supply and demand. While one of the main forms of the mobility of on-line labour is real-time programming, there are also other forms; IT subsidiaries in China, owned by Chinese living in Japan, are an example. In recent years, many of the Chinese living in Japan have set up IT companies. In the Tokyo region alone there are 200. A good $50 \%$ of them are small or medium-size enterprises which employ about ten workers, and often have to fight for survival in the very competitive Japanese market.

Many of these companies have a branch in China, which is the offspring of its "concealed base camp" in Japan. Whereas the parent company in Tokyo is usually small-scale, its Chinese subsidiary has a large workforce, as well as a high capability for technological development and organised distribution. The creation of these subsidiaries mostly depends on the relations which the head of the parent company established when he was living in China. Very often these connections are with the founder's former fellow students at university, former colleagues at work, or even members of his family. A great many of the orders placed by the parent company in Tokyo are the result of close co-operation between it and its subsidiary in China. The case of the Chinese entrepreneurs in Japan resembles that of the Indian programmers, in that value is not created within the national territory. Other common features can be identified:

Limited direct contact between the IT workers in the subsidiaries in China and the parent company in Japan.

Labour mobility has a transnational character even while it occurs within the national borders. The Chinese authorities do not consider this kind of activity to be a brain drain; on the contrary, they encourage it. For their part, the Japanese authorities keep a careful watch, but there has been no outspoken attack on it. In effect, labour is exported to Japan, but without having to undergo any change in identity.

IT workers in China, while being integrated into the pattern of local employment in China, are nonetheless directly filling gaps in the Japanese demand for labour.

Unlike classical exports, this mobile labour is not subject to import restrictions, taxes or customs duties.

As the number of subsidiary companies in China increases, so there is a fall in Japanese demand for IT workers recruited there to work in Japan. This fall in the demand for workers on the ground is in direct proportion to the rising demand for workers on-line. There is a symbiotic interaction between the two.

28 Taken together, these factors define the features of the virtual migration between the IT subsidiaries in China and the Chinese-owned parent companies in Japan. 
Future developments in the offshore space between China and Japan: three possible scenarios

The developments in on-line and in situ IT operations, in terms of both quantity and quality, might suggest that we are about to witness a rapid increase in the number of bilingual engineers. In reality, however, the very nature of this kind of employment demands a long period of training, so the number of applicants is still limited and is growing only very slowly. As a result we do not see a rapid increase in the number of Chinese living in Japan with an engineer's visa. On the other hand, the number of short-term visits by Chinese IT workers has greatly increased, and this probably corresponds to a growth in the number of re-entries in that sector. So it seems that a large number of Chinese IT worker immigrants are getting around Japan's labour immigration laws.

30 A possible scenario for future development is that, contrary to the views put forward by Japanese politicians in favour of admitting foreign IT workers (including the introduction of a green card in the near future), job growth in the information sector will reach its limit. This thesis is supported by the fact that the mobility of "brains" not requiring physical travel is more or less overlooked in the statistics. For as long as the Japanese government fails to take account of this, the gap between its policy of attracting foreign IT workers and the requirements of the actual situation will persist.

31 According to a second possible scenario, both business logic and the characteristics of software production are combining to produce the development of an alternative, invisible migration between China and Japan. The more Japanese companies support the extension of large-scale production in China, the less will they feel the need to bring IT workers to Japan. Or in other terms, the greater the growth in offshore labour, the less the number of migrants on the ground. We call this phenomenon between China and Japan "the ratchet effect" 5 .

32 This kind of interrelatedness can also be found in the case of orders for software production between India and the United States, but with some differences. The main difference concerns the role of the domestic market. In India $80 \%$ of software production is for export, since the domestic market is still under-developed. In China, the domestic market is enormous and still growing. Although the export market for software is also expanding rapidly, it still represents less than $10 \%$ of the market as a whole. This has a direct impact on the IT workers' desire to emigrate. At first, Japanese companies sought to optimise the use of cheap labour, but they have ended up by developing co-operative relations aimed at the Chinese market.

A second difference concerns language. Indian professionals have no problem, either in communicating with their American customers or in developing software in English. By contrast, in the case of Sino-Japanese software development, the language barrier presents a real problem. So in general, direct exchanges of personnel are more necessary than between India and the United States. The presence of bilingual engineers has turned out to be the key to success or failure in the joint development of software. Yet, even today, the majority of Chinese IT workers prefer to go to the United States, if they have to emigrate at all. Japan is less attractive than the English-speaking countries, especially the United States.

34 The third scenario is based upon the idea of a segmented labour market, which was first propounded in the 1960s, to address the distinction between Black and White labour ${ }^{6}$. Modified and brought up to date, this idea is still useful for analysing the 
division of labour between Japan and China in the IT sector. Currently most of the orders placed by Japan with Chinese producers are low-cost and short-term, involving tasks which could be carried out (but may be turned down) in Japan. Japanese IT companies take advantage of the social and economic differences between the two countries to have the work done more cheaply in China. And the Chinese companies consent to do the work at local rates, believing that by working for Japanese customers they can improve their technical abilities and know-how. Now that these relations are in place, it seems unlikely that the Japanese IT orders will be taken away from the Chinese. So in the realm of IT production, a regional Sino-Japanese space is emerging. In other words, we can divide the labour market created by this situation into two levels, the first consisting of the highly qualified labour in Japan, and the second consisting of less qualified workers in China. This does not include the entire Chinese IT market, only a part of the software market for export. So the IT sector is characterised by the existence of two labour markets, each of which is located within a nation state, and developing in symbiosis with each other. The overall situation could be called a segmented transnational labour market.

However, it is almost inconceivable that as the Chinese IT firms grow increasingly more powerful, they will continue to be satisfied with hiring relatively unqualified workers for much longer. And as the Chinese domestic market develops further, Japan will inevitably have to modify her policies. This means that the current double structure of the IT labour market will necessarily have to develop towards co-operative relations on an equal footing. 
How technological developments have changed our concept of migration

According to Aneesh ${ }^{7}$, the continuous growth of the global economy creates an environment in which the information industries give birth to a new form of migration, namely "on-line migration", which can be described as a dimension of the new international division of labour. Aneesh makes a distinction between two types of migration. The first concerns work in situ, which presupposes actual moving abroad. Since physical movement is involved, overseas recruitment is also called "body shopping" ${ }^{8}$. This form of migration has already been studied in many treatises, and it will continue. The second and more recent type of migration, which has not been studied much, is on-line labour mobility. This form of mobility is particularly visible in the case of IT programmers operating between India and the United States. Unlike overseas recruitment, in which the mobility of both the technology and the person as physical entity go together, in the case of on-line programming the technology circulates without the physical movement of people.

By using the new technical means which enable the transmission of highly compressed data, programmers have on-line and real time access to any computer in the world, without leaving their own country. These workers, like their employers, are therefore free of all the formalities required by physical travel. In Aneesh's view, on-line migration has the following three features:

direct face-to-face contact between on-line workers and those who issue their instructions from abroad are very limited

on-line employees do not have to undergo the experiences of seeking a foreign work permit, of being an alien resident, of facing local xenophobia, or having to adapt culturally-they can maintain their cultural identity

while on-line workers remain within the employment system of their own country, they directly meet the needs of a part of the labour market in the country of those who give them instructions.

Aneesh describes these workers in terms of a "virtual migration". The emergence of this phenomenon is closely linked to the changes in the organisation of labour brought about by technological innovations-namely, the textualisation and dematerialisation of labour itself. The developments in the organisation of labour enabled by information technology have made transnational labour, like on-line working, possible. A new form of labour has arisen, and it is transforming the realities of foreign trade, sub-contracting, and overseas placement.

Unlike classical imports, on-line labour mobility is never subject to quotas, taxes or customs duties. Although on-line labour crosses national frontiers on a daily basis, there is no mechanism for regulating it.

Secondly, the economic activities of the Indian IT companies have practically no relationship with the production of commercial software. On the contrary, a large proportion of these companies specialise in the export of labour, whether in the form of recruitment for work overseas or for online working. In 1999, according to statistics put out by Nasscom ${ }^{9}$, the export of labour accounted for $91.2 \%$ of these companies' profits, whereas the creation of commercial software only represented $8.8 \%$.

Finally, the nature of the contracted work in situ is hardly any different from on-line work. And in fact, the falling demand for workers in situ is directly linked to the rising demand for on-line workers. The two demands are interactively related.

The above argument advanced by Aneesh is based on the case of Indian programmers in the United States, but his approach is equally pertinent for studying one section of the Chinese IT workers in Japan. His concepts of "overseas recruitment" and "virtual migration" in particular, provide useful analytical tools.

Chinese entrepreneurs in Silicon Valley and Xinzhu in Taiwan

Annalee Saxenian's studies of the transnational community of Chinese entrepreneurs operating between California's Silicon Valley and Taiwan's Xinzhu are now universally acclaimed ${ }^{10}$. Until the 1980s, the most advanced American technology only moved in one direction, from US territory to Taiwan, but in the 1990s a new type of labour organisation arose, brought about by the actions of such transnational entrepreneurs. This system of shared influence at the top is based on a give-

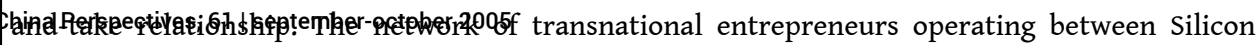
Valley and Taiwan, is mostly made up of Taiwanese graduates from US universities.

According to Annalee Saxenian, transnational communities are "mechanisms for the long distance transmission of knowledge, and are potentially more flexible and responsive than companies. When such transmission occurs between places where the company's culture and the 


\section{NOTES}

1. The media serving the Chinese community in Japan include newspapers in Chinese. of these, Zhongwen daobao is the second oldest, after Ryuugakusei shimbun (liu xuesheng xinwen). It pays its way thanks to a wide circulation, and it enjoys a reputation for its lively reporting, consistently maintained over ten years, on the life of the Chinese community in Japan. Its articles can be found on the internet at http:// www.chubu.com/. This site is largely supported nowadays by the paper's subsidiary in Shanghai.

2. In 2002 , for example, out of the total 3,209 work permits granted to foreign graduates in Japan, 1,933 went to Chinese students-over 60\% (statistics provided by the Ministry of Justice, http://www.moj.go.jp).

3. Zhongwen daobao, June 28th 2001, p. 10.

4. The 3Ks stand for kitanai, kitsui, kiken (dirty, boring, dangerous).

5. The so-called "ratchet effect" refers to its interconnecting drives.

6. Peter Doeringer and Michael Piore, Internal Labor Market and Manpower Analysis, New York and London, M.E. Shape, 1971.

7. Aneesh Aneesh, "Rethinking Migration: On-line Labor Flows from India to the United States", The International Migration of the Highly Skilled: Demand, Supply, and Development Consequences in Sending and Receiving Countries, Center for Comparative Immigration Studies, University of California, San Diego, 2001.

8. I use the more neutral concept of overseas recruitment, even though this misses some of the nuances of "body shopping".

9. Nasscom is the acronym for the Indian "National Association of Software and Service Companies".

10. Annalee Saxenian, "Silicon Valley to Taiwan Xinzhu connection - Gijutsu Community to Sangyou no Koudoka (The community of engineers and hi-tech production)", in Tenkanki no Higashi Ajia to Nihon Kigyou (New Directions for East Asia and Japanese Companies), 2000.

11. Ibidem, p. 319.

12. Ibid, p. 317.

13. Ibid, p. 316 .

14. Ibid, p. 348 . 


\section{RÉSUMÉS}

A large number of Chinese engineers work in the information technology (IT) sector in Japan, mostly in software programming. Having been recruited in China or Japan, these IT workers do not form a homogeneous group and are subject to very different working conditions. Parallel to this recruitment of Chinese IT workers, Japanese industry "imports" Chinese labour through online working. An increasing number of IT workers are employed by Japanese firms without leaving their own country, thanks to systems for on-line transmission of highly compressed data. 